University of Nebraska - Lincoln

DigitalCommons@University of Nebraska - Lincoln

Faculty Publications from the Harold W. Manter Laboratory of Parasitology

$11-1989$

\title{
An Alternative Approach for Evaluating the Efficacy of Potential Biocontrol Agents of Weeds. 2. Path Analysis
}

\author{
Dan J. Pantone \\ University of California - Davis \\ William A. Williams \\ Louisiana Agricultural Experiment Station \\ Armand R. Maggenti \\ University of California - Davis
}

Follow this and additional works at: https://digitalcommons.unl.edu/parasitologyfacpubs

Part of the Parasitology Commons

\begin{abstract}
Pantone, Dan J.; Williams, William A.; and Maggenti, Armand R., "An Alternative Approach for Evaluating the Efficacy of Potential Biocontrol Agents of Weeds. 2. Path Analysis" (1989). Faculty Publications from the Harold W. Manter Laboratory of Parasitology. 618.

https://digitalcommons.unl.edu/parasitologyfacpubs/618
\end{abstract}

This Article is brought to you for free and open access by the Parasitology, Harold W. Manter Laboratory of at DigitalCommons@University of Nebraska - Lincoln. It has been accepted for inclusion in Faculty Publications from the Harold W. Manter Laboratory of Parasitology by an authorized administrator of DigitalCommons@University of Nebraska - Lincoln. 


\section{An Alternative Approach for Evaluating the Efficacy of Potential Biocontrol Agents of Weeds. 2. Path Analysis 1}

DAN J. PANTONE, WILLIAM A. WILLIAMS, and ARMAND R. MAGGENTI ${ }^{2}$

\begin{abstract}
Path analysis was used to assess the efficacy of the fiddleneck flower gall nematode as a weed biocontrol agent of coast fiddleneck in competition with wheat during 2 yr of field experiments. The path analysis revealed that the number of inflorescences/plant for fiddleneck and the number of heads/plant for wheat were the most important yield components that determine fecundity and seed yield. The density of fiddleneck had a much greater impact on the yield components of fiddleneck than did the density of wheat or the nematode rate of inoculation. The nematode had its greatest negative impact on the number of seeds/flower of fiddleneck and its greatest positive impact on the number of heads/plant of wheat. Path analysis predicts that a biocontrol agent that has a large negative direct effect on the number of inflorescences/plant for fiddleneck would be more efficacious in decreasing fecundity and seed yield than an agent that only impacts the number of flowers/ inflorescence, seeds/flower, or biomass/seed. Nomenclature: Coast fiddleneck, Amsinckia intermedia Fischer and Meyer \#3 AMSIN; wheat, Triticum aestivum L. 'Anza'; fiddleneck flower gall nematode, Anguina amsinckiae (Steiner and Scott, 1935) Thorne, 1961.

Additional index words. Yield components, biological control, competition, interference, nematodes, Amsinckia intermedia, Triticum aestivum, Anguina amsinckiae, AMSIN.
\end{abstract}

\section{INTRODUCTION}

Although the inverse linear model used in the first paper of this series (13) can be an exceptionally informative method for investigating the impact of herbivores on plant competition, it does not take into account many important variables that help describe the population biology of plants. Furthermore, parameters such as the number of seeds/plant (fecundity), total seed biomass/plant (seed yield), biomass/ seed (seed weight), number of seeds/flower, number of flowers/inflorescence, and number of inflorescences/plant were not used with this model originally (17). Incorporating data from additive designs into a path analysis could increase our basic understanding of how stress caused by herbivores

\footnotetext{
${ }^{1}$ Received for publication June 16,1989 , and in revised form October 6, 1989.

${ }^{2}$ Postgrad. Res. and Prof., Dep. Agron. and Range Sci., and Prof., Dep. Nematol., Univ. California, Davis, CA 95616, respectively. Present address of senior author: Dep. Plant Pathol. and Crop Physiol., Louisiana Agric. Exp. Stn. ${ }_{3}$ Louisiana State Univ. Agric. Ctr., Baton Rouge, LA 70803.

${ }^{3}$ Letters following this symbol are a WSSA-approved computer code from Composite List of Weeds, Weed Sci. 32, Suppl. 2. Available from WSSA, 309 West Clark Street, Champaign, II 61820.
}

and plant competition influences plants at the population level.

The method of path analysis was developed by a population geneticist $(20,21)$. Path analysis has been used extensively by animal breeders and geneticists, but rarely to investigate competition or the impact of herbivores or pathogens on plants $(6,19)$. Path analysis has been used to analyze local variations in plant size in a neighborhood model of plant performance (12). Neighborhood competition models employ regression or correlation analysis to estimate fecundity or size of a focal plant by using variables such as the number, biomass, dispersion, or growth form of its neighboring plants. Local site quality and the effects of competition may be confounded in neighborhood competition models, and path analysis may permit an estimation of site quality (12). Recently, path analysis was used to assess the impact of seedling establishment, growth form, and growth rate on the shoot biomass production of poorjoe (Diodia teres Walt.) (9). Moreover, an agricultural weed population of poorjoe was compared to a coastal nonweed population, and the weed population had a larger early growth rate and greater establishment rate compared to the nonweed coastal population.

In this report we show how path analysis can be used in plant population ecology to: a) reveal which yield components are most important in determining fecundity and seed yield; b) elucidate indirect effects and opposing effects among yield components that might otherwise hide their importance; and c) indicate the impact of herbivores and competition on yield components.

\section{MATERIALS AND METHODS}

The impact of the fiddleneck flower gall nematode on its host (coast fiddleneck) was evaluated during $2 \mathrm{yr}$ of field experiments. Details of the additive experimental design have been described previously (13). Results of the additive design (inverse linear model) were used for a path analysis. Five nematode inoculation rates were included for the path analysis $\left(0,10^{3}, 10^{4}, 10^{5}\right.$, and $10^{6}$ nematodes per plot). Nine variables were recorded: number of seeds/plant (fecundity), total seed biomass (g)/plant (seed yield), biomass (g)/100 seeds (seed weight), number of seeds/flower (or seeds/ spikelet for wheat), number of flowers/inflorescence (or spikelets/head for wheat), number of inflorescences/plant (or heads/plants for wheat), fiddleneck density, wheat density, and nematode inoculation rate. A path analysis was constructed and the impact of the nematode and competition on the population ecology of the plants illustrated (Figures 1 and 2). Standardized partial regression coefficients and simple correlation coefficients were calculated $(5,15)$. Residual 
WEED SCIENCE
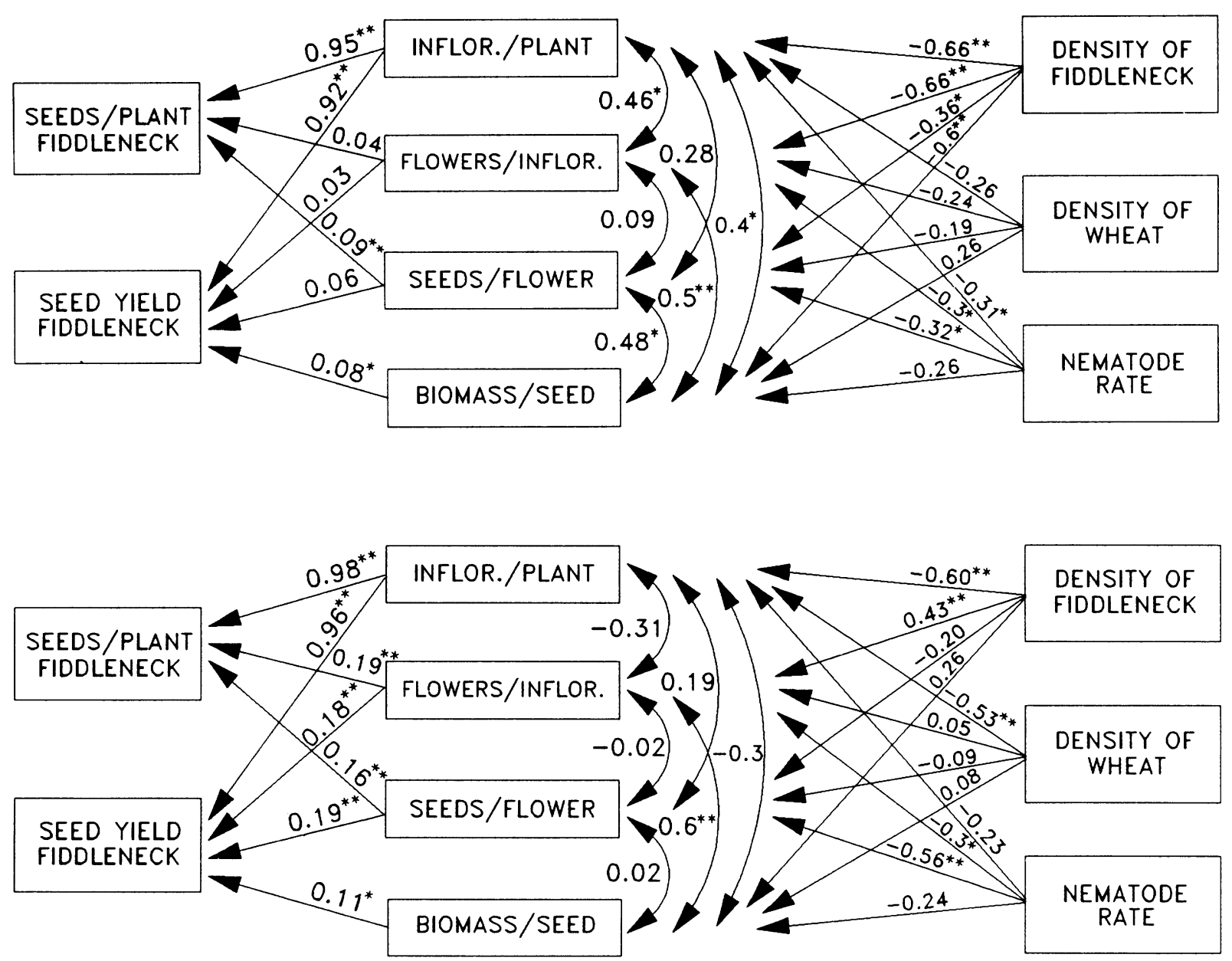

Figure 1. Path diagram for the relationships between plant densities and nematode rate of inoculation and the yield components of fiddleneck. Single-arrowed lines represent direct influences measured by path coefficients, and the double-arrowed lines indicate correlation coefficients. Seed yield refers to total seed biomass ( $\mathrm{g}$ )/ plant, and Inflor. denotes inflorescences. 1986-87 season on top, 1987-88 season on bottom. Coefficients with asterisks are significantly different from zero: *, $\mathrm{P}<0.05$ or ${ }^{* *}, \mathrm{P}<0.01$.

factors included all unlisted variables that influence fecundity or seed yield, including sampling errors. Uncorrelated residual factors $(\mathrm{U})$ were estimated by the relationship $\mathrm{U}=$ $\sqrt{1-R^{2}}$, where $R$ is the multiple correlation coefficient (1, 10).

Path analysis permits the partitioning of the correlation coefficients between the dependent variable and the independent variables into direct and indirect effects $(4,10,11$, 20, 21). A direct effect is called a path coefficient and is a standardized partial regression coefficient. Basically, this method is an application of the normal equations used in linear regression analysis of data that are standardized in a closed system (10). In order to specify the nature and direction of the proposed correlational structure, a path diagram is used (Figure 3). The variables can be grouped in a relational diagram containing hypothesized pathways of the influence of plant competition and herbivores on plant reproduction. A direct effect is depicted by a unidirectional arrow, while an indirect effect is represented by a two-headed arrow plus a unidirectional arrow. Path coefficients can be obtained by the simultaneous solution of the normal equations for multiple regression in standard measure. For a model with three independent variables and one dependent variable,

$$
\begin{aligned}
& r_{14}=P_{14}+r_{12} P_{24}+r_{13} P_{34} \\
& r_{24}=P_{24}+r_{12} P_{14}+r_{23} P_{34} \\
& r_{34}=P_{34}+r_{13} P_{14}+r_{23} P_{24}
\end{aligned}
$$

where $\mathrm{r}_{\mathrm{ij}}$ represent the correlation coefficients between the dependent variable (variable 4) and each independent variable, $P_{i j}$ are the path coefficients (direct effects), and $r_{i j} P_{i j}$ are the indirect effects (Figure 3). Different path diagrams can be proposed for the same system allowing alternative causal 


\section{PANTONE ET AL.: PATH ANALYSIS FOR EVALUATING EFFICACY}

hypotheses to be tested. Mathematically speaking, the arrangement fixed by the researcher is completely arbitrary. However, to be meaningful the results of path analysis must be consistent in structure and congruous with the observations.

The path analysis used is very conservative in that the dependent variables (fecundity and seed yield) are the products of the independent variables (yield components). For example, seed number/plant is the product of the number of inflorescences/plant, the number of flowers/inflorescence, and the number of seeds/flower (inflorescences and flowers cancel out) (Figure 1).

Note that there are no two-headed arrows (simple correlations) between fiddleneck density, wheat density, and the nematode rate of inoculation (Figures 1 and 2). The values of these three variables were chosen by the researchers and are uncorrelated. The standardized partial regression coefficients are equal to the correlation coefficients in this special case (16).

\section{RESULTS AND DISCUSSION}

The path analysis indicated that the direct influence of the four yield components (inflorescences or heads/plant, flowers/ inflorescence or spikelets/head, seeds/flower or seeds/spikelet, and biomass/seed) on fecundity and seed yield was positive (Figures 1 and 2). The number of inflorescences or heads/plant was by far the most important variable that determines fecundity and seed yield. Moreover, all significant simple correlations between the four yield components were positive. Therefore, this was not a situation where resources are sacrificed from one yield component in order to increase another component. For example, a negative correlation between seeds/flower and biomass/seed was hypothesized. Fiddleneck is in the Boraginaceae and normally produces a maximum of four seeds/flower. If the number of seeds/flower of the weeds was sacrificed to increase the seed weight, there would have been a negative correlation instead of a positive one. Contrary to our hypothesis, plants with more seeds/
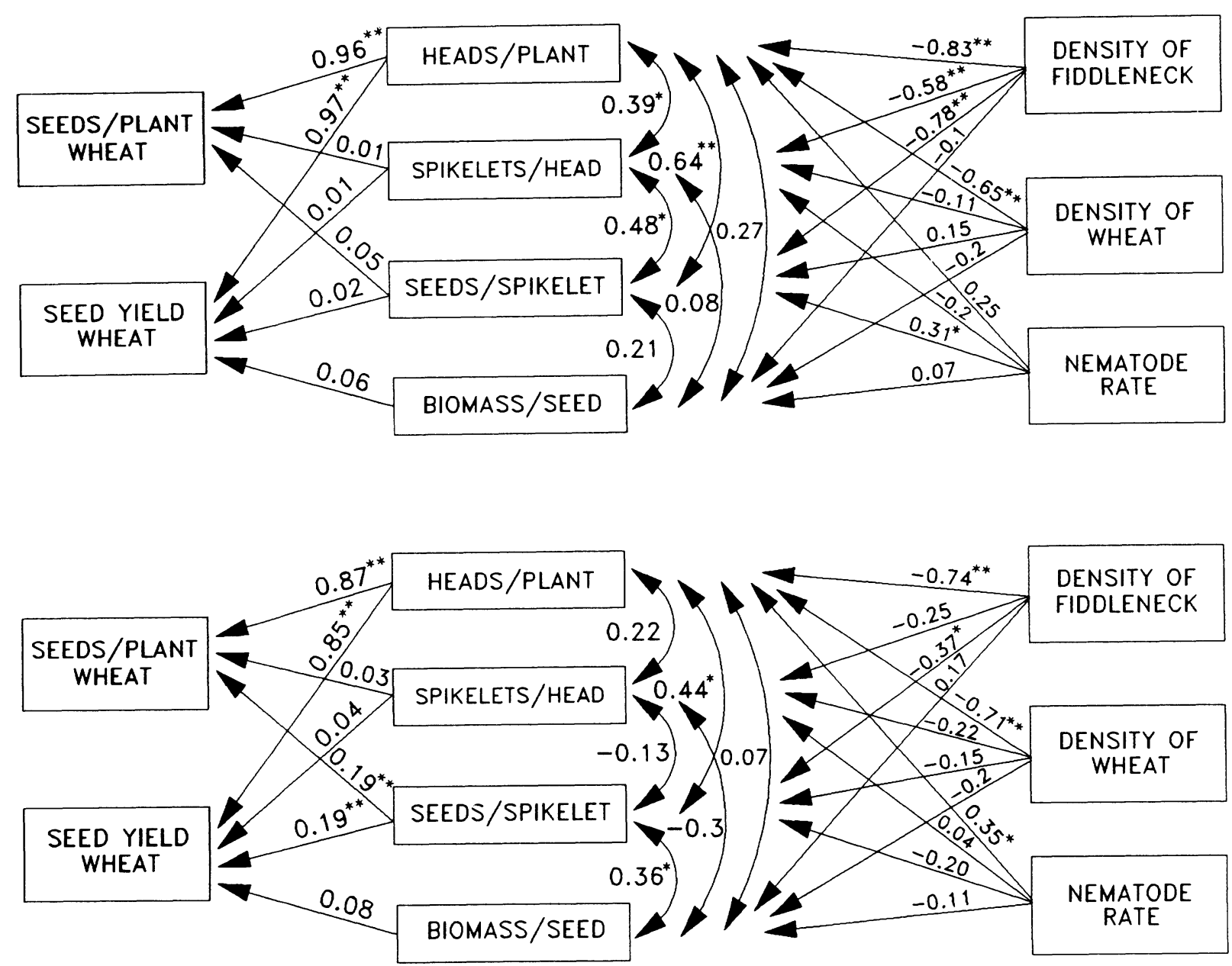

Figure 2. Path diagram for the relationships between plant densities and nematode rate of inoculation and the yield components of wheat. Single-arrowed lines represent direct influences measured by path coefficients, and the double-arrowed lines indicate correlation coefficients. Seed yield refers to total seed biomass (g)/ plant. 1986-87 season on top, 1987-88 season on bottom. Coefficients with asterisks are significantly different from zero: *, $P<0.05$ or $* *, P<0.01$. 


\section{WEED SCIENCE}

flower tend to have larger seeds as well. The coefficients of determination ( $\mathrm{R}^{2}$ values) were high, ranging from 0.94 to 0.99 , for the multiple regressions in which the yield components were the independent variables and fecundity and seed yield were the dependent variables. Consequently, the residual factors $(U)$ were relatively small $(0.24$ to 0.10$)$.

The influence of increasing fiddleneck or wheat density is generally negative on the yield components. The only deviation from this pattern was a significant positive path coefficient (0.43) from fiddleneck density to flowers/ inflorescence in the 1987-88 season (Figure 1). In the previous season, the direct effect of increasing fiddleneck density on the number of flowers/inflorescence was negative $(-0.66)$. Fiddleneck density was more important than wheat density in its impact on fiddleneck or wheat yield components, and the greatest impact of fiddleneck was on inflorescences and heads/plant.

It was possible to calculate the value of a path coefficient in terms of its constituent paths (16). For example, to estimate the direct effect of fiddleneck density on seeds/plant (via inflorescences/plant) during the 1986-87 season, the direct effect of inflorescences/plant on seeds/plant (0.95) was multiplied by the direct effect of fiddleneck density on inflorescences/plant $(-0.66)$ to obtain -0.63 . Therefore, the compound path was the product of the component paths.

Overall, the nematode had its greatest direct effect on seeds/flower for fiddleneck and heads/plant for wheat during the 1987-88 season. The impact of the nematode was significantly negative for fiddleneck and positive for wheat (Figures 1 and 2). Furthermore, the nematode also had a significant negative impact on inflorescences/plant and flowers/inflorescence (1986-87 season only) of fiddleneck, but had no significant effect on biomass/seed. There was a significant positive impact by nematodes on seeds/spikelet for wheat during the 1986-87 season and on the number of heads/plant in 1987-1988. The results of the path analysis predict that the herbivore or pathogen that had the greatest negative impact on fiddleneck inflorescences/plant would be the best biocontrol agent. A biocontrol agent that had a

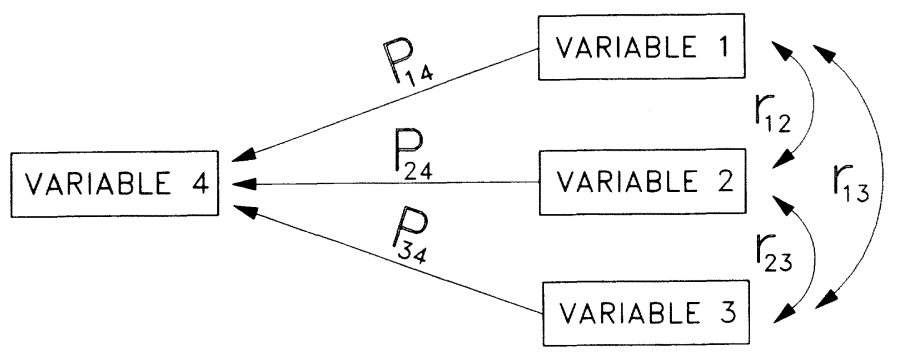

Figure 3. Path diagram for a model with three independent variables and one dependent variable. $P_{i j}$ represents path coefficients and $r_{i j}$ represents simple correlation coefficients. There are three different paths from an independent variable to the dependent variable. For Variable 1 , the three paths are: $P_{14}$ (direct effect), $r_{12} P_{24}$ (indirect effect via Variable 2), and $r_{13} P_{34}$ (indirect effect via Variable 3 ). The sum of the direct and indirect effects equals $r_{14}$, the simple correlation coefficient. negative direct effect on only the number of flowers/ inflorescence, seeds/flower, or biomass/seed and not on inflorescences/plant would probably be less efficacious as a biocontrol agent of fiddleneck, assuming the relationships between the yield components and yield variables remained constant.

It might be possible to breed or genetically engineer biocontrol agents $(2,18)$ to have a greater negative impact on fiddleneck inflorescences/plant using this technique. Herbivores and pathogens that are most efficacious as weed biocontrol agents may not always be favored by natural selection. Hokkanen and Pimentel $(7,8)$ have suggested that an evolved equilibrium may have selected for herbivores which are less injurious to their hosts. They speculate that the result of a long-term evolutionary relationship between a herbivore and a plant is an interspecific homeostasis in which both species can coexist without injuring each other severely. However, they fail to mention that in many systems this premise is dependent on group selection rather than individual selection. Whichever the case, path analysis may provide a useful method to artificially select for effective biological weed control agents.

The striking similarity of the path analysis diagrams for fiddleneck and wheat may be explained in part due to similarities in their morphology; both species produce determinant inflorescences. Therefore, the number of flowers/ inflorescence (or spikelets/head) did not change greatly. The number of seeds/flower (or seeds/spikelet) and biomass/seed did not vary to any great extent in either species. Consequently, the number of inflorescences (or heads) was the only component of yield that varied enough to have a large direct influence on fecundity or seed yield. The results of the path analysis may have been different if the plants studied had indeterminate instead of determinate inflorescences. Additionally, the other yield components might be more plastic in the presence of other agents. In a study by Clements et al. (3), wheat was sown at densities of 40,80 , 160,320 , and 640 seeds $/ \mathrm{m}^{2}$ and several plant variables were measured at plant maturity. Plant height, stem diameter, and the number of spikelets/head were relatively stable. In contrast, tillering was very plastic and the number of heads/ plant decreased at higher densities which is similar to what we observed. Puckeridge and Donald (14) planted wheat at various densities and observed a 43-fold variation in head number, but only a 1.7 -fold variation in seeds/head and negligible variation in seed weight. The number of heads/ plant ranged from 1 to 23 (23-fold), seeds/head from 4 to 46 (11.5-fold), and seed weight per 100 seeds form 3.0 to $4.2 \mathrm{~g}$ (1.4-fold) in our studies.

It is unwise to assume that simple correlation coefficients represent causal relationships; path analysis can reveal to what extent simple correlations are due to direct effects. For example, the number of flowers/inflorescence had significant positive correlations (0.48 and 0.49$)$ with seeds/plant and seed yield, respectively, during the 1986-87 season (Table 1). However, the path coefficients (direct effects) were 0.04 and 0.03 , respectively, and were not significant. The number of flowers/inflorescence was significantly correlated with fecundity and yield because of the indirect effects via inflorescences/plant (Table 1). Similarly, in the 1986-87 season, 


\section{PANTONE ET AL.: PATH ANALYSIS FOR EVALUATING EFFICACY}

spikelets/head and seeds/spikelets had relatively small direct effects on seeds/plant and seed yield and their significant correlations were due to indirect effects via heads/plant (Table 2).

The primary purpose of this study was to demonstrate how path analysis and the inverse linear model (13) might be used to assess potential biocontrol agents, but not to determine if the nematode is the best potential biocontrol agent for fiddleneck. To do the latter, the ranking of the nematode against other potential agents would be necessary, a task

Table 1. Path coefficient analysis of fiddleneck. Pathways of association between the yield variables and yield components.

\begin{tabular}{|c|c|c|}
\hline Pathways of association & Year 1 & Year 2 \\
\hline $\begin{array}{l}\text { Seeds/plant vs. inflorescences/plant: } \\
\text { Direct effect } \\
\text { Indirect effect via flowers/inflorescence } \\
\text { Indirect effect via seeds/flower }\end{array}$ & $\begin{array}{l}0.95^{* *} \\
0.02 \\
0.02\end{array}$ & $\begin{array}{c}0.98^{* *} \\
-0.06 \\
0.03\end{array}$ \\
\hline Total correlation & $0.99 * *$ & $0.95^{* *}$ \\
\hline $\begin{array}{l}\text { Seed/plant vs. flowers/inflorescence: } \\
\text { Direct effect } \\
\text { Indirect effect via inflorescences/plant } \\
\text { Indirect effect via seeds/flower }\end{array}$ & $\begin{array}{l}0.04 \\
0.43 \\
0.01\end{array}$ & $\begin{array}{c}0.19 * * \\
-0.31 \\
0.00\end{array}$ \\
\hline Total correlation & $0.48^{* *}$ & -0.12 \\
\hline $\begin{array}{l}\text { Seed/plant vs. seeds/flower: } \\
\text { Direct effect } \\
\text { Indirect effect via inflorescences/plant } \\
\text { Indirect effect via flowers/inflorescence }\end{array}$ & $\begin{array}{l}0.09^{* *} \\
0.26 \\
0.01\end{array}$ & $\begin{array}{l}0.16^{* *} \\
0.18 \\
0.00\end{array}$ \\
\hline Total correlation & $0.36^{*}$ & $0.34^{*}$ \\
\hline $\begin{array}{l}\text { Seed yield vs. inflorescences/plant: } \\
\text { Direct effect } \\
\text { Indirect effect via flowers/inflorescence } \\
\text { Indirect effect via seeds/flower } \\
\text { Indirect effect via biomass/seed }\end{array}$ & $\begin{array}{l}0.92^{* *} \\
0.02 \\
0.02 \\
0.03\end{array}$ & $\begin{array}{l}0.96^{* *} \\
-0.05 \\
0.04 \\
-0.03\end{array}$ \\
\hline Total correlation & $0.99 * *$ & $0.92 * *$ \\
\hline $\begin{array}{l}\text { Seeds yield vs. flowers/inflorescence: } \\
\text { Direct effect } \\
\text { Indirect effect via inflorescences/plant } \\
\text { Indirect effect via seeds/flower } \\
\text { Indirect effect via biomass/seed }\end{array}$ & $\begin{array}{l}0.03 \\
0.42 \\
0.00 \\
0.04\end{array}$ & $\begin{array}{l}0.18^{* *} \\
-0.29 \\
0.00 \\
0.07\end{array}$ \\
\hline Total correlation & $0.49^{* *}$ & -0.04 \\
\hline $\begin{array}{l}\text { Seed yield vs. seeds/flower: } \\
\text { Direct effect } \\
\text { Indirect effect via inflorescences/plant } \\
\text { Indirect effect via flowers/inflorescence } \\
\text { Indirect effect via biomass/seed }\end{array}$ & $\begin{array}{l}0.06 \\
0.26 \\
0.00 \\
0.04\end{array}$ & $\begin{array}{c}0.19 * * \\
-0.19 \\
0.00 \\
0.00\end{array}$ \\
\hline Total correlation & $0.36^{*}$ & $0.38^{*}$ \\
\hline $\begin{array}{l}\text { Seed yield vs. biomass/seed: } \\
\text { Direct effect } \\
\text { Indirect effect via inflorescence/plant } \\
\text { Indirect effect via flowers/inflorescence } \\
\text { Indirect effect via seeds/flowers }\end{array}$ & $\begin{array}{l}0.08^{*} \\
0.37 \\
0.01 \\
0.03\end{array}$ & $\begin{array}{c}0.11^{*} \\
-0.26 \\
0.12 \\
0.00\end{array}$ \\
\hline Total correlation & $0.49 * *$ & -0.03 \\
\hline
\end{tabular}

$$
* \mathrm{P}<0.05 \text {. }
$$$$
* * \mathrm{P}<0.01 \text {. }
$$

beyond our current resources. It was our goal to show that the agencies responsible for screening and introducing biological weed control agents could adopt the suggested approach. The benefits of such an approach would be multiple. The direct applied benefits would involve the biocontrol of weeds, in which data bases could be developed that predict which organisms have the greatest potential by assessing their impact on the population biology of plants. Moreover, the data generated by the applied studies would be a boon for ecologists. Many ecologists assert that plant competition and

Table 2. Path coefficient analysis of wheat. Pathways of association between the yield variables and yield components.

\begin{tabular}{|c|c|c|}
\hline Pathways of association & Year 1 & Year 2 \\
\hline $\begin{array}{l}\text { Seeds/plant vs. heads/plant: } \\
\text { Direct effect } \\
\text { Indirect effect via spikelets/head } \\
\text { Indirect effect via seeds/spikelet }\end{array}$ & $\begin{array}{l}0.96 * * \\
0.00 \\
0.03\end{array}$ & $\begin{array}{l}0.87^{* *} \\
0.01 \\
0.08\end{array}$ \\
\hline Total correlation & $0.99 * *$ & $0.96 * *$ \\
\hline $\begin{array}{l}\text { Seed/plant vs. spikelets/head: } \\
\text { Direct effect } \\
\text { Indirect effect via heads/plant } \\
\text { Indirect effect via seeds/spikelet }\end{array}$ & $\begin{array}{l}0.01 \\
0.37 \\
0.03\end{array}$ & $\begin{array}{r}0.03 \\
0.19 \\
-0.03\end{array}$ \\
\hline Total correlation & 0.41 & 0.19 \\
\hline $\begin{array}{l}\text { Seed/plant vs. seeds/spikelet: } \\
\text { Direct effect } \\
\text { Indirect effect via heads/plant } \\
\text { Indirect effect via spikelets/head }\end{array}$ & $\begin{array}{l}0.05 \\
0.61 \\
0.01\end{array}$ & $\begin{array}{l}0.19 * * \\
0.38 \\
0.00\end{array}$ \\
\hline Total correlation & $0.67^{* *}$ & $0.57 * *$ \\
\hline $\begin{array}{l}\text { Seed yield vs. heads/plant: } \\
\text { Direct effect } \\
\text { Indirect effect via spikelets/head } \\
\text { Indirect effect via seeds/spikelet } \\
\text { Indirect effect via biomass/seed }\end{array}$ & $\begin{array}{l}0.97 * * \\
0.00 \\
0.01 \\
0.01\end{array}$ & $\begin{array}{l}0.85^{* *} \\
0.01 \\
0.08 \\
0.01\end{array}$ \\
\hline Total correlation & $0.99 * *$ & $0.95^{* *}$ \\
\hline $\begin{array}{l}\text { Seeds yield vs. spikelets/head: } \\
\text { Direct effect } \\
\text { Indirect effect via heads/plant } \\
\text { Indirect effect via seeds/spikelet } \\
\text { Indirect effect via biomass/seed }\end{array}$ & $\begin{array}{l}0.01 \\
0.38 \\
0.01 \\
0.00\end{array}$ & $\begin{array}{r}0.04 \\
0.19 \\
-0.03 \\
-0.03\end{array}$ \\
\hline Total correlation & $0.40^{*}$ & 0.17 \\
\hline $\begin{array}{l}\text { Seed yield vs. seeds/spikelet: } \\
\text { Direct effect } \\
\text { Indirect effect via heads/plant } \\
\text { Indirect effect via spikelets/head } \\
\text { Indirect effect via biomass/seed }\end{array}$ & $\begin{array}{l}0.02 \\
0.62 \\
0.00 \\
0.01\end{array}$ & $\begin{array}{l}0.19 * * \\
0.38 \\
-0.01 \\
0.03\end{array}$ \\
\hline Total correlation & $0.65^{* *}$ & $0.59 * *$ \\
\hline $\begin{array}{l}\text { Seed yield vs. biomass/seed: } \\
\text { Direct effect } \\
\text { Indirect effect via heads/plant } \\
\text { Indirect effect via spikelets/head } \\
\text { Indirect effect via seeds/spikelet }\end{array}$ & $\begin{array}{l}0.06 \\
0.26 \\
0.00 \\
0.00\end{array}$ & $\begin{array}{r}0.08 \\
0.06 \\
-0.01 \\
0.07\end{array}$ \\
\hline Total correlation & 0.32 & 0.20 \\
\hline
\end{tabular}

$* \mathrm{P}<0.05$.

$* * \mathrm{P}<0.01$. 


\section{WEED SCIENCE}

herbivory are the most important processes that structure plant communities, and the proposed approach would allow them to test basic ecological theories on a large scale.

\section{LITERATURE CITED}

1. Afifi, A. A. and V. Clark. 1984. Path analysis. Pages 235-237 in Computer-Aided Multivariate Analysis. Lifetime Learning Publications, Belmont, CA.

2. Charudattan, R. 1985. The use of natural and genetically altered strains of pathogens for weed control. Pages 347-372 in D. Herzog and M. Hoy, eds. Biological Control in Agricultural IPM Systems. Academic Press, New York.

3. Clements, F. E., J. E. Weaver, and H. C. Hanson. 1929. Competition in cultivated crops. Carnegie Inst. Wash. Publ. 398:202-233.

4. Dewey, D. R. and K. H. Lu. 1959. A correlation and path-coefficient analysis of components of crested wheatgrass seed production. Agron. J. 51:515-518.

5. Draper, N. R. and H. Smith. 1981. Applied Regression Analysis. 2nd ed. Pages 257-266. John Wiley and Sons, New York.

6. Hampton, R. D. 1975. The nature of bean yield reduction by bean yellow and bean common mosaic viruses. Phytopathology 65: 1342-1346.

7. Hokkanen, H. 1985. Exploiter-victim relationships of major plant diseases: Implications for biological weed control. Agric., Ecosystems, and Environ. 14:63-76.

8. Hokkanen, H. and D. Pimentel. 1984. New approach for selecting biological control agents. Can. Entomol. 116:1109-1121.
9. Jordan, N. 1989. Path analysis of growth differences between weed and nonweed populations of poorjoe (Diodia teres) in competition with soybean (Glycine max). Weed Sci. 37:129-136.

10. Li, C. C. 1975. Path Analysis - A Primer. Boxwood Press, Pacific Grove, CA. 347 pp.

11. Loehlin, J. C. 1987. Latent Variable Models: An Introduction to Factor, Path, and Structural Analysis. L. Erlbaum Associates, Hillsdale, NJ. 273 pp.

12. Mitchell-Olds, T. 1987. Analysis of local variation in plant size. Ecology 68:82-87.

13. Pantone, D. J., W. A. Williams, and A. R. Maggenti. 1989. An alternative approach for evaluating the efficacy of potential biocontrol agents of weeds. 1. Inverse linear model. Weed Sci. 37:771-777.

14. Puckeridge, D. W. and C. M. Donald. 1967. Competition among wheat plants sown at a wide range of densities. Aust. J. Agric. Res. 18: 193-211.

15. SAS Institute. 1985. SAS User's Guide: Statistics. Version 5 ed. Pages 655-709. SAS Institute, Cary, NC.

16. Sokal, R. R. and F. J. Rohlf. 1981. Biometry. 2nd ed. Pages 642-661. W. H. Freeman, New York.

17. Spitters, C.J.T. 1983. An alternative approach to the analysis of mixed cropping experiments. 1. Estimation of competition effects. Neth. J. Agric. Sci. 31:1-11.

18. Templeton, G. E. 1988. Biological control of weeds. Am. J. Alternative Agric. 3:69-72.

19. van Bruggen, A.H.C. and P. A. Ameson. 1986. Path coefficient analysis of effects of Rhizoctonia solani on growth and development of dry beans. Phytopathology 76:874-878.

20. Wright, S. 1921. Correlation and causation. J. Agric. Res. 20:557-585.

21. Wright, S. 1934. The method of path coefficients. Ann. Math. Statistics 5:161-215. 